\title{
A Case-Crossover Design to Examine the Role of Aeroallergens and Respiratory Viruses on Childhood Asthma Exacerbations Requiring Hospitalization: The Mapcah Study
}

Bircan Erbas ${ }^{1 *}$, Shyamali C Dharmage ${ }^{2}$, Molly O'Sullivan', Muhammad Akram ${ }^{3}$, Ed Newbigin ${ }^{4}$, Philip Taylor $^{5}$, Don Vicendese ${ }^{1}$, Rob $^{1}$ Hyndman $^{6}$, Philip Bardin ${ }^{7}$, Mimi L Tang ${ }^{8}$ and Michael J Abramson ${ }^{9}$

${ }^{1}$ School of Public Health, La Trobe University, Melbourne, VIC, Australia

${ }^{2}$ Centre for Molecular, Environmental, Genetic \& Analytic Epidemiology, School of Population Health, The University of Melbourne, Melbourne, VIC, Australia

${ }^{3}$ Department of Epidemiology and Preventive Medicine, School of Public Health \& Preventive Medicine, Monash University, Melbourne, Australia

${ }^{4}$ School of Botany, The University of Melbourne, Melbourne, Australia

${ }^{5}$ School of Life and Environmental Sciences, Deakin University, Melbourne, Australia

${ }^{6}$ Department of Econometrics and Business Statistics, Monash University, Melbourne, Australia

${ }^{7}$ Department of Respiratory and Sleep Medicine, Monash Medical Centre, Melbourne, VIC, Australia

${ }^{8}$ Department of Allergy \& Immunology, Royal Children's Hospital, Melbourne, Australia; Allergy and Immune Disorders, Murdoch Childrens Research Institute, Melbourne

Australia; Department of Paediatrics, University of Melbourne, Australia

${ }^{9}$ Department of Epidemiology and Preventive Medicine, Monash University, Melbourne, VIC, Australia

\begin{abstract}
Background: Few case-control studies of time dependent environmental exposures and respiratory outcomes have been performed. Small sample sizes pose modeling challenges for estimating interactions. In contrast, case cross-over studies are well suited where control selection and responses are low, time consuming and costly.
\end{abstract}

Objective: To demonstrate feasibility in daily recruitment of children admitted to hospital with asthma and validity of the case crossover methodology for hospital based studies.

Methods: The Melbourne Air Pollen Children and Adolescent Health (MAPCAH) study recruited incident asthma admissions of children and adolescents aged 2-17 years to a tertiary hospital. A case was defined by date of admission, and eligible cases served as their own controls. We used bi-directional sampling design for control selection. At time of admission, participants underwent skin prick tests and nasal/throat swabs (NTS) to test for respiratory viruses. Questionnaires collected data on asthma management, family history and environmental characteristics. Daily concentrations of ambient pollen, air pollution and weather variables were also available.

Results: 644 children were recruited. More than half (63\%) were male with mean age 5.2(SD 3.3) years. Nonparticipants were slightly younger at admission (mean age 4.4, SD 2.8, p<0.001), although the absolute differences were small. Participants and non-participants were well balanced on gender. The most common reason for refusal to participate in the study was "causing further distress to child by skin prick testing". Gender and age distributions were similar to the overall admissions to the tertiary hospital as well as in Victoria. Our study slightly under-represented winter admissions $(p<0.001)$, and was over-represented in spring $(p<0.001)$. More admissions occurred during the grass pollen season in our study than in general asthma hospital admissions across Victoria $(42 \%$ versus $22 \%, p<0.001)$.

Conclusions: The case cross-over method is a highly feasible design for a reasonably sized hospital based study of children with asthma. MAPCAH has robust internal validity and strong generalizability. Collection of data on respiratory viruses and pollen exposure at the time of admission on children with asthma provides important information that will have clinical and public health impacts.

Keywords: Case crossover design; Asthma; Respiratory viral infections; Internal validity

\section{Introduction}

In Australia, UK and the US, asthma is the leading long term health condition in children aged 0 to 15 years [1-3]. If not managed properly, asthma is one of the most frequent reasons for hospital admissions in children aged between 0 and 10 years in Australia [4], between 0 and 4 years in the UK [5] and between 5 and 11 years in the US [6].

Sudden-onset asthma exacerbations requiring hospitalization can be triggered by a number of different factors, depending on the severity of asthma. The commonest factors that trigger exacerbations in children are environmental, such as pollen exposure [Erbas et al., 2012 under review], air pollution [7], viral respiratory infections [8], and abrupt changes in weather, such as thunderstorm-related asthma $[9,10]$. Children with asthma will be at the most risk, as they are more susceptible to abrupt changes in the environment, resulting in sudden peaks in hospital admissions [11].
Most studies, including our own prior work, have used aggregated daily time series data at the population level to examine associations between outdoor pollen and asthma morbidity $[7,12,13]$. These studies have limited applicability, because they do not have access to individual clinical data such as asthma severity, the presence of respiratory viral infections and data on family history. Although most have used

*Corresponding author: Bircan Erbas, School of Public Health, La Trobe University, Bundoora, Victoria 3086, Australia, Tel: +61 39479 5657; Fax: +61 3 9479 1783; Email: b.erbas@latrobe.edu.au

Received April 09, 2012; Accepted June 22, 2012; Published June 23, 2012

Citation: Erbas B, Dharmage SC, O'Sullivan M, Akram M, Newbigin E, et al. (2012) A Case-Crossover Design to Examine the Role of Aeroallergens and Respiratory Viruses on Childhood Asthma Exacerbations Requiring Hospitalization: The Mapcah Study. J Biomet Biostat S7-018. doi:10.4172/2155-6180.S7-018

Copyright: ( $) 2012$ Erbas B, et al. This is an open-access article distributed unde the terms of the Creative Commons Attribution License, which permits unrestricted use, distribution, and reproduction in any medium, provided the original author and source are credited. 
Citation: Erbas B, Dharmage SC, O'Sullivan M, Akram M, Newbigin E, et al. (2012) A Case-Crossover Design to Examine the Role of Aeroallergens and Respiratory Viruses on Childhood Asthma Exacerbations Requiring Hospitalization: The Mapcah Study. J Biomet Biostat S7-018. doi:10.4172/2155-6180.S7-018

the "season" as a marker of respiratory viruses [14] this may not be adequate, as recent studies have shown that the human rhinovirus (HRV) infection circulates at different times of the year [15]. Others have used hospital based case-control designs to examine the combined impact of these risk factors, but these have not had sufficient power to be able to adequately detect interactions $[8,16]$

In recent years, the hospital-based case-crossover design has received a lot of attention in studies of environmental factors and respiratory health [17-21]. Case-crossover designs are useful in investigating the impacts of environmental exposures on health outcomes that are expected to occur shortly after exposure, while controlling for factors that do not vary over specific time periods [22]. Control selection is based on specific periods prior to and following the day of admission. These periods are based on the time series distribution of the exposure variable, such as day of the week, lagged effects etc. Because cases have already been recruited into the study and they act as their own control (during the referent time periods) matched controls are readily available. The case crossover methodology allows the inclusion of other important time-varying risk factors such as the presence of other allergens, parental smoking, or indoor environment. This methodology is highly suited to large epidemiological studies where both control selection and responses are low, time consuming and costly.

We have conducted a study of hospital admissions for asthma in children and adolescents using a case-crossover design. The aims were to: (a) estimate the effects of outdoor levels of pollen and fungal spores on asthma hospital admissions in children and (b) determine whether these estimated effects were different in children with respiratory viral infection or on high pollution days.

The aim of this manuscript is to illustrate feasibility in daily recruitment of children admitted to hospital with asthma and validity of the case crossover methodology for hospital based studies. Here, we describe the methods and recruitment rates of Melbourne Air Pollen Children and Adolescent Health (MAPCAH) study and compare responders and non-responders as well as over all admissions in Victoria in order to evaluate the internal and external validity.

\section{Methods}

\section{Study design and population}

The MAPCAH study is a hospital-based case-crossover study of incident asthma admissions in children and adolescents. The inclusion criteria were all cases aged 2-17 years when admitted to the Royal Children's Hospital ( $\mathrm{RCH})$ in Melbourne, Victoria, with a principal diagnosis code of asthma (J45). The exclusion criteria were children under 2 years of age, parents/guardians unable to complete the questionnaire due to language difficulties and patients who lived more than $50 \mathrm{~km}$ outside $\mathrm{RCH}$. The index (case) period was defined as the date of admission, and eligible cases served as their own controls. Controls were sampled for respiratory viral infections during the "referent time periods" (see below).

\section{Case cross-over methodology}

Following Navidi and Weinhandl (2002) [23] for the case crossover we define $t$ as the time that a child is likely to be admitted to hospital at times $\mathrm{T}_{1}, \ldots, \mathrm{T}_{\mathrm{n}}$ with exposure levels defined as $\mathrm{X}_{1}, \ldots, \mathrm{X}_{\mathrm{n}}$. Let $\mathrm{T}_{k}$ be the actual time of admission (independent event) also defined as the case event.

We used a bi-directional design, with the referent time period as the control window so that the controls would be matched by 7 days.
The choice of a bi-directional design for the control period reduces the potential biases as a result of possible time trends in the exposure time series.

The risk set $\mathrm{R}$ will now consist of $\left\{\mathrm{T}_{\mathrm{k}-21}, \mathrm{~T}_{\mathrm{k}-\mathrm{l}}, \mathrm{T}_{\mathrm{k}+1}, \mathrm{~T}_{\mathrm{k}+21}\right\}$ where $\mathrm{l}$ is a short lag chosen as 7 days for this study.

The data were stratified into four control "referent" periods and an index case period. For example, if an index case occurred on the $15^{\text {th }}$ January (say that this is a Monday) the exposure of a case will be compared to the exposure two Mondays before the index case event and two Mondays after the index case event. This allows control for day of week effects.

To estimate the risk parameter $\beta$ the standard conditional logistic regression likelihood is used:

$$
\frac{e^{\beta X_{k}}}{e^{\beta X_{k-2 l}}+e^{\beta X_{k-l}}+e^{\beta X_{k}}+e^{\beta X_{k+l}}+e^{\beta X_{k+2 l}}}
$$

We are interested in estimating the percentage increase in risk for an interquartile (IQR) increase using the following formula

$$
\left(\beta^{I Q R}-1\right) \times 100
$$

As the odds ratio (OR) $e^{\beta}$, and $95 \% \mathrm{CI}$ of OR $e^{\beta} \pm 1.96 S E\left(e^{\beta}\right)$.

\section{Sampling methods and recruitment}

To achieve adequate power (greater than 80\%) for the study, over 250 children sensitised to aeroallergens were required. The sample size estimate was based on $45 \%$ recruitment response, odds ratios ranging from 1.5 to 2.5 and a two-sided level of significance set at 0.05 .

All eligible cases were identified through the admissions office of the $\mathrm{RCH}$. A study information pack, including a plain language statement and consent forms, was given to the parents/guardians of likely participants. With parental consent, all participants underwent a skin prick test shortly after admission, nasal and throat swabs (NTS) were also obtained to test for respiratory viral infections. We administered a questionnaire (based on validated ISAAC and ICAAM questionnaires) $[24,25]$ to collect data on indoor/outdoor lifestyle factors, current and past asthma management, and family history of asthma and allergies. These questionnaires were completed at or before the collection of the second NTS sample, nine weeks (this was the median rather than the intended time of resampling) after the admission date (see Respiratory Viral Infections section)

\section{Definition of Outcomes and Exposure Measurement}

\section{Definition of asthma}

We cross-checked the diagnoses at admission and discharge to ensure all participants had asthma. We developed an asthma severity score (classified as infrequent / frequent / intermittent, mild, moderate / severe / persistent) based on the National Asthma Council guidelines [26]. We also accessed clinical records of the treatment details; as well as data on the presence of a wheeze, vital signs, oxygen saturation level, and whether this was a repeat admission. We did not measure lung function ( $\mathrm{PEF}$ and $\mathrm{FEV}_{1}$ ), as the median age of our participants was 4 years, and children under 7 years were unlikely to be able to perform these tests reliably.

\section{Outdoor pollen and fungal spores}

Airborne pollen (classified as grass, tree, weed and other) and 
Citation: Erbas B, Dharmage SC, O'Sullivan M, Akram M, Newbigin E, et al. (2012) A Case-Crossover Design to Examine the Role of Aeroallergens and Respiratory Viruses on Childhood Asthma Exacerbations Requiring Hospitalization: The Mapcah Study. J Biomet Biostat S7-018. doi:10.4172/2155-6180.S7-018

fungal spores (Cladosporium and Alternaria) were collected daily over the study period using a volumetric spore trap in accordance with the guidelines of the World Allergy Organisation. The trap was located on the Parkville campus of The University of Melbourne at a site that conforms to the relevant Australian standard, as described by Erbas et al. (2007) [27].

For each admission date (case) we matched the daily level of pollen and fungi on the admission date. As all environmental exposures were collected daily we were able to match pollen and fungi levels on days designated as control days for each case. We used a similar matching for pollution and weather data.

\section{Allergy skin testing}

After recruitment, skin prick tests (SPTs) were performed with appropriate controls for a panel of pollens (rye grass, seven grass mix, birch pollen, English plantain and ten tree mix), fungal allergens (Alternaria and Cladosporium) and common food allergens (egg white and peanut), as well as house dust mites and cat allergens (HollisterStier, Spokane, WA, USA; Alyostal, Antony, France). A positive result was defined as a reaction with a size of $3 \mathrm{~mm}$ or greater to one or more of the allergens in the presence of positive histamine and negative saline controls.

\section{Respiratory viral infections}

Nasal and throat swabs (NTS) were collected from each participant to test for respiratory viruses both when they are initially admitted to hospital for asthma and nine weeks after their index admission (during the control period). We tested for respiratory viruses [influenza A (including $\mathrm{pH} 1 \mathrm{~N} 1$ ) and $\mathrm{B}$, picornavirus (rhinovirus), respiratory syncytial virus (RSV), parainfluenza, coronavirus and adenovirus]. Testing for respiratory viruses is done using a sensitive nested multiplex PCR, amplifying specific and conserved sequences for viruses including influenza A and B, adenoviruses, RSV, coronaviruses OC43, 229e and NL63, picornaviruses and parainfluenza viruses 1, 2 and 3. Testing and genotyping have been described elsewhere [28].

\section{Outdoor air pollution and weather data}

The 24-hour average daily concentrations $\left(\mu \mathrm{g} / \mathrm{m}^{3}\right)$ of Particulate Matter $<2.5$ and $10 \mu \mathrm{m}$ diameter $\left(\mathrm{PM}_{25}\right.$ and $\left.\mathrm{PM}_{10}\right)$, daily maximum one-hour averages of nitrogen dioxide $\left(\mathrm{NO}_{2}\right)$ in parts per billion (ppb), and daily maximum four-hour averages of ozone $\left(\mathrm{O}_{3}\right)$ in ppb were obtained from the Victorian Environment Protection Authority (EPA), which operates routine monitoring stations across Melbourne. We also accessed data on the daily maximum temperature, daily rainfall ( $\mathrm{mm})$, 4-hourly wind speed ( $\mathrm{km} /$ hour), and average daily relative humidity (percentage) from the Bureau of Meteorology.

\section{Assessment of internal and external validity}

To determine whether the characteristics of those who declined to participate in the study were different from those of the MAPCAH participants (internal validity), we administered a short one page questionnaire to parents/guardians who did not wish to participate in the study. The anonymous questionnaire included questions on the gender, age and prior history of asthma of the child, the reason for non-response and the family history of asthma and allergies. To determine the extent to which our findings could be generalized to the target population of childhood asthma admissions (external validity) we compared our data with two other data sets: the Victoria Linkage data of all childhood asthma hospital admissions between 2008 and 2009, and daily childhood asthma admissions to the Royal Children's Hospital (Victoria) between 2009 and 2011.

\section{Results}

In this section we only present MAPCAH data on recruitment and findings to examine internal and external validity. A total of 2019 children were admitted with respiratory symptoms, of which 1084 were eligible and invited to participate in the study. We missed 212 children when we were not recruiting during weekends or when they were discharged early from the hospital. Skin prick tests were completed on all participants at admission. All children completed an NTS at admission, and 631 had NTS both at index admission and at a median of nine weeks later, with 13 children lost to follow-up. In Melbourne, the months of October through to December are typically those with the highest levels of airborne grass pollen and these months loosely define a grass pollen season. During the study period 644 children participated in the study.

A total of 644 children were recruited (74\% recruitment rate) on a daily basis between September 2009 and December 2011 (Figure 1 black square - participants, red triangle - non participants).

Table 1 displays each participant's characteristics. Of those recruited, 407 (63\%) were male, the mean age was 5.2 years (SD 3.3), and over half of the children had a personal history of hay fever or eczema. More than half the children were skin-test positive to house dust mites (HDM), 49\% were sensitized to ANY pollen, 14\% were sensitized to fungi, and approximately $23 \%$ tested positive to egg or peanut allergens. $70 \%$ of all children had a positive NTS for human rhinovirus (HRV) at admission and $21 \%$ were still positive nine weeks after the index admission. No pandemic influenza (H1N1/2009) was detected. Over half the children had a parent with a history of asthma and hay fever. In comparison, approximately $35 \%$ of children reported a parental history of eczema.

\section{Internal validity}

There were 228 children who met the eligibility criteria at admission, but declined to participate in the study. We were able to

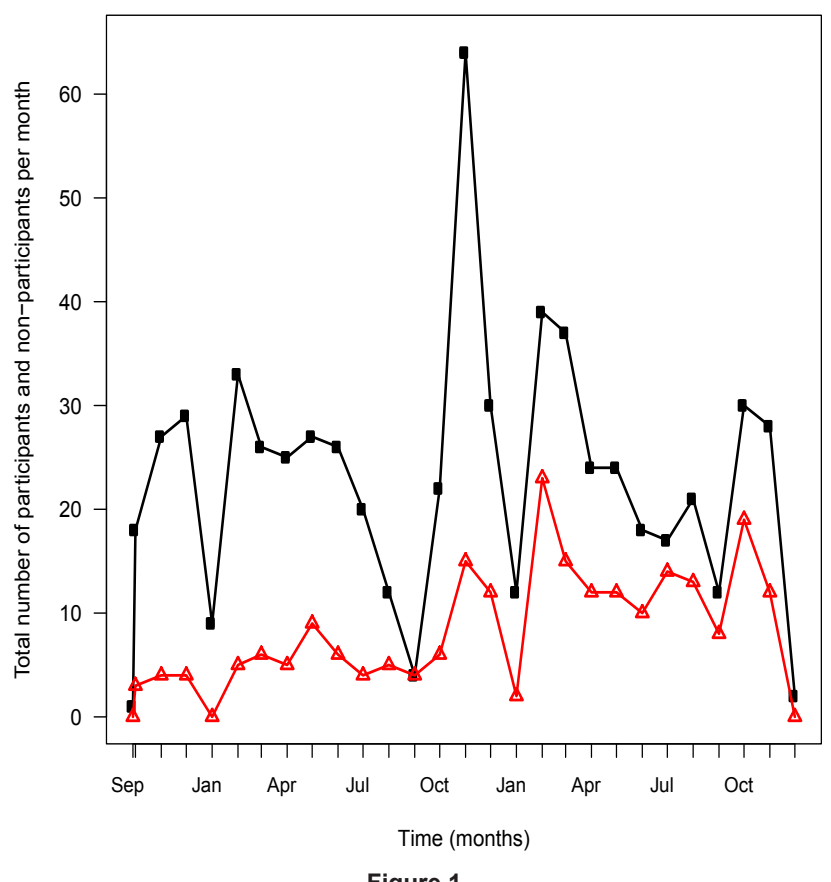

Figure 1 
Citation: Erbas B, Dharmage SC, O'Sullivan M, Akram M, Newbigin E, et al. (2012) A Case-Crossover Design to Examine the Role of Aeroallergens and Respiratory Viruses on Childhood Asthma Exacerbations Requiring Hospitalization: The Mapcah Study. J Biomet Biostat S7-018. doi:10.4172/2155-6180.S7-018

Page 4 of 6

\begin{tabular}{|c|c|}
\hline & $\begin{array}{l}\text { MAPCAH } \\
\text { Participants }\end{array}$ \\
\hline & $\mathrm{N}=644(\%)$ \\
\hline $\begin{array}{l}\text { Gender } \\
\text { - Male } \\
\text { - Female }\end{array}$ & $\begin{array}{l}407(63 \%) \\
237(37 \%)\end{array}$ \\
\hline Age (Yrs) mean Sd & $5.2 \pm 3.3$ \\
\hline $\begin{array}{l}\text { Age (Yrs - categories) } \\
-2 \text { to } 4 \\
\cdot 5 \text { to } 10 \\
\cdot 11+\end{array}$ & $\begin{array}{r}352(55 \%) \\
228(35 \%) \\
64(10 \%)\end{array}$ \\
\hline $\begin{array}{l}\text { Pollen season admittance (Oct-Jan) } \\
\text { No } \\
\text { Yes }\end{array}$ & $\begin{array}{l}373(58 \%) \\
271(42 \%)\end{array}$ \\
\hline $\begin{array}{l}\text { Has Eczema } \\
\text { No } \\
\text { Yes }\end{array}$ & $\begin{array}{l}N=639 \\
275(43 \%) \\
364(57 \%)\end{array}$ \\
\hline $\begin{array}{l}\text { Has Hay fever } \\
\text { No } \\
\text { Yes }\end{array}$ & $\begin{array}{l}N=639 \\
300(47 \%) \\
339(53 \%)\end{array}$ \\
\hline $\begin{array}{l}\text { Repeat admission (within } 28 \text { days of admis- } \\
\text { sion) } \\
\text { No } \\
\text { Yes }\end{array}$ & $\begin{array}{l}n=624 \\
599(96 \%) \\
25(4 \%)\end{array}$ \\
\hline $\begin{array}{l}\text { Sensitisation at admission } \\
\text { HDM } \\
\text { Food } \\
\text { - Peanut } \\
\text { - egg }\end{array}$ & $\begin{array}{l}N=643 \\
368(57 \%) \\
147(23 \%) \\
106(16 \%) \\
83(13 \%)\end{array}$ \\
\hline $\begin{array}{l}\text { Fungi } \\
\text { - Alternaria } \\
\text { - Cladosporium }\end{array}$ & $\begin{array}{l}88(14 \%) \\
57(9 \%) \\
44(7 \%)\end{array}$ \\
\hline $\begin{array}{l}\text { Pollen } \\
\cdot \text { Birch } \\
\cdot \text { English Plantain } \\
\cdot 7 \text { grass mix } \\
\cdot \text { Rye grass } \\
\cdot 10 \text { tree mix }\end{array}$ & $\begin{array}{l}313(49 \%) \\
78(12 \%) \\
118(18 \%) \\
222(35 \%) \\
241(37 \%) \\
47(7 \%)\end{array}$ \\
\hline $\begin{array}{l}\text { Presence of Respiratory virus at admission } \\
\text { No } \\
\text { HRV } \\
\text { Other }\end{array}$ & $\begin{array}{l}N=642 \\
179(28 \%) \\
447(70 \%) \\
16(2 \%)\end{array}$ \\
\hline $\begin{array}{l}\text { Presence of Respiratory virus at follow-up } \\
\text { (2nd NTS) } \\
\text { No } \\
\text { HRV } \\
\text { Other }\end{array}$ & $\begin{array}{l}N=628 \\
471(75 \%) \\
135(21 \%) \\
22(4 \%)\end{array}$ \\
\hline $\begin{array}{l}\text { Presence of Respiratory virus at admission } \\
\text { and follow up } \\
\text { No } \\
\text { HRV } \\
\text { Other }\end{array}$ & $\begin{array}{l}N=629 \\
129(21 \%) \\
98(16 \%) \\
1(0.2 \%) \\
N=629\end{array}$ \\
\hline $\begin{array}{l}\text { Family history of atopy } \\
\text { Mother asthma } \\
\text { Mother hay fever } \\
\text { Mother eczema }\end{array}$ & $\begin{array}{l}196(31 \%) \\
290(46 \%) \\
171(27 \%)\end{array}$ \\
\hline $\begin{array}{l}\text { Father asthma } \\
\text { Father hay fever } \\
\text { Father eczema }\end{array}$ & $\begin{array}{r}184(29 \%) \\
268(43 \%) \\
94(15 \%) \\
\end{array}$ \\
\hline
\end{tabular}

\begin{tabular}{|c|c|c|c|}
\hline & $\begin{array}{l}\text { MAPCAH } \\
\text { Partici- } \\
\text { pants } \\
\mathrm{N}=644\end{array}$ & $\begin{array}{l}\text { Non-con- } \\
\text { sent } \\
N=228\end{array}$ & $\begin{array}{l}\text { P value compar- } \\
\text { ing MAPCAH } \\
\text { participants and } \\
\text { Non-consent }\end{array}$ \\
\hline $\begin{array}{l}\text { Male } \\
\text { Age (Yrs) - mean SD } \\
\text { Age (Yrs - categories) } \\
2 \text { to } 4 \\
5 \text { to } 10 \\
11+ \\
\text { First presentation asthma } \\
\text { - No } \\
\text { - Yes } \\
\text { Admission during the pollen season } \\
\text { (Oct to Jan) } \\
\text { - No } \\
\text { - Yes } \\
\text { Season of admission } \\
\text { - Autumn } \\
\text { - Winter } \\
\text { - Spring } \\
\text { - Summer }\end{array}$ & $\begin{array}{l}407(63 \%) \\
5.2 \pm 3.3 \\
\\
352(55 \%) \\
228(35 \%) \\
64(10 \%) \\
486(75 \%) \\
158(25 \%) \\
\\
373(58 \%) \\
271(42 \%) \\
163(25 \%) \\
119(18 \%) \\
210(33 \%) \\
152(24 \%)\end{array}$ & $\begin{array}{c}144(63 \%) \\
4.4 \pm 2.8 \\
154(67 \%) \\
65(29 \%) \\
9(4 \%) \\
171(75 \%) \\
57(25 \%)\end{array}$ & $\begin{array}{l}0.0277 \\
\\
0.8660 \\
0.1571 \\
0.6835 \\
0.2885\end{array}$ \\
\hline
\end{tabular}

Table 2: Comparison of MAPCAH clinical cohort with non-participants.

\begin{tabular}{|c|c|c|c|}
\hline & $\begin{array}{l}\text { MAPCAH } \\
\text { Partici- } \\
\text { pants } \\
\mathrm{N}=644\end{array}$ & $\begin{array}{l}\text { General asthma } \\
\text { admissions } \\
\text { To all Victorian } \\
\text { Hospitals } \\
\mathrm{N}=7415\end{array}$ & $\begin{array}{l}\text { P value compar- } \\
\text { ing MAPCAH } \\
\text { participants to } \\
\text { General admis- } \\
\text { sions to all Vic- } \\
\text { torian hospitals }\end{array}$ \\
\hline $\begin{array}{l}\text { Male } \\
\text { Age (Yrs) - mean SD } \\
\text { Age (Yrs - categories) } \\
2 \text { to } 4 \\
5 \text { to } 10 \\
11+ \\
\text { First presentation asthma } \\
\text { - No } \\
\text { - Yes } \\
\text { Admission during the pollen } \\
\text { season (Oct to Jan) } \\
\text { - No } \\
\text { - Yes } \\
\text { Season of admission } \\
\text { - Autumn } \\
\text { - Winter } \\
\text { - Spring } \\
\text { - Summer }\end{array}$ & $\begin{array}{l}407(63 \%) \\
5.2 \pm 3.3 \\
352(55 \%) \\
228(35 \%) \\
64(10 \%) \\
\\
486(75 \%) \\
158(25 \%)\end{array}$ & $\begin{array}{l}5773(78 \%) \\
1642(22 \%) \\
\\
2201(30 \%) \\
1974(26 \%) \\
1708(23 \%) \\
1532(21 \%)\end{array}$ & $\begin{array}{l}<0.001 \\
0.0194 \\
<0.001 \\
<0.001 \\
0.0782\end{array}$ \\
\hline
\end{tabular}

Table 3: Comparison of MAPCAH clinical cohort with asthma admissions to Victorian hospitals.

to the participants, non-participants were slightly younger at admission (mean age $=4.4, \mathrm{SD}=2.8, \mathrm{p}<0.001$ ), although the absolute differences were small. Participants and non-participants were well balanced on gender (both predominantly male) and on asthma diagnosis prior to admission to hospital. A greater proportion of our study participants were admitted during the pollen season ( $42 \%$ versus $34 \%, \mathrm{p}<0.03$ ). The seasonal distribution of admissions was roughly similar between participants and non-participants, although non-participants were slightly more likely to be admitted during the winter months. These findings reflect less participation at younger ages.

\section{External validity}

To examine the external validity of our study, we compared the gender, age and season of admissions between our study participants and all childhood asthma hospital admissions in Victoria (Table 3). The gender and age distributions were relatively similar. Our study participants were slightly under-represented among winter admissions $(p<0.001)$, and slight over-represented in spring and summer $(p<0.001$ and $p<0.007$ respectively). More admissions occurred during the pollen 
Citation: Erbas B, Dharmage SC, O'Sullivan M, Akram M, Newbigin E, et al. (2012) A Case-Crossover Design to Examine the Role of Aeroallergens and Respiratory Viruses on Childhood Asthma Exacerbations Requiring Hospitalization: The Mapcah Study. J Biomet Biostat S7-018. doi:10.4172/2155-6180.S7-018

season in our study than in general asthma hospital admissions across Victoria ( $42 \%$ versus $22 \%, p<0.001$ ).

We also compared the characteristics of our study participants with those of childhood asthma admissions to the Royal Children's Hospital (Victoria) over the recruitment period. There were no differences in the distributions of age or prior admissions for asthma. Children admitted to the study hospital during the study period were slightly younger on average $($ mean age $=4.9 \mathrm{SD}=3.1 \mathrm{p}<0.03)$. The seasonal distribution and admissions during the pollen season were the same (data not shown).

\section{Discussion}

To the best of our knowledge, this is the first case-crossover study of childhood asthma admissions to simultaneously examine the role of outdoor pollen and fungi exposure and determine whether individual-specific factors, such as sensitization status, the presence of respiratory viral infections, and family history, modify these associations. The MAPCAH study has designed and successfully implemented a minimally invasive, but sufficiently detailed case crossover methodology highly suitable for hospital based investigations of children with asthma. We have obtained a high recruitment rate of $74 \%$, and have shown that our study design has a robust internal validity and strong generalizability. Furthermore, this study was highly feasible as the case crossover design was well suited for a hospital based recruitment strategy. When examining environmental exposures such as pollen, hospital-based outcomes case-crossover designs are advantageous over case-control studies because of low participation, particularly among controls. As a consequence, it has been difficult to model interactions between other variables and the exposure such as the presence of respiratory viruses.

We found no differences in the gender and seasonal distributions of admissions when we compared the characteristics of non-participants and participants. Although the non-participants were slightly younger, they were more likely to be admitted during the winter months, suggesting a respiratory viral trigger for the hospital admission. However, the absolute differences were relatively modest, suggesting bias was unlikely.

We found no differences in age or gender when we compared our study participants with general childhood asthma admissions in Victoria, Australia. However, in our study a greater proportion of admissions occurred during months when airborne grass pollen levels in Melbourne are likely to be high (October through to December). This may have been the result of a number of peaks in grass pollen that occurred during the study recruitment period. These peaks were not observed in the general childhood asthma admissions in Victoria. There was no difference between the characteristics of our study participants and those of asthma admissions to the Royal Children's Hospital over the recruitment period. This suggests that our study findings can be generalized to the target population of childhood asthma admissions.

Almost all studies on ambient exposures to pollen and childhood asthma hospital admissions or emergency department presentations (ED) have utilised a population-based ecological time series design [2931]. In all of these studies, positive associations between the exposure to pollen and asthma exacerbations requiring ED presentations or hospitalisation were observed. However, they were limited by lack of individual-level data such as clinical characteristics, the presence of respiratory infections, family history, parental smoking and other lifestyle factors. At best, age-specific differences in the observed associations were examined [32]. Our study is a significant advance on these previous studies that have reported on similar outcomes and pollen exposure.

The selection of a representative sample of controls and low control participation are major issues in case-control studies of populationbased hospital designs. To the best of our knowledge, only two studies have used case-control designs to examine ambient pollen exposures and hospital based outcomes for asthma in children $[8,16]$.

Murray et al. (2006) [8] used monthly data over a one-year period with 125 eligible cases, 84 agreed to participate (67\% response rate) and were matched to controls. Power was a major limitation as the authors were unable to conduct strata-specific analyses to assess possible three-way interactions between the exposure to grass pollen, allergic sensitisation and the presence of a respiratory virus at admission.

Galan and colleagues (2010) [16] also conducted a case-control study for examining airborne pollen sensitisation and asthma peaks in Spain in children and adults combined, aged 4 to 79 years. During the May-June peak season, of the 154 eligible cases $61.7 \%$ agreed to participate in the study and of the controls $51.6 \%$ agreed to participate. They too were unable to conduct strata-specific analysis and also didn't include clinical characteristics, respiratory viruses and family history in the models due to due to the relatively small sample size. Days with high levels of particulate matter, are known to interact with ambient levels of pollen. None of these studies to date have included air pollutants when examining these associations.

\section{Strengths}

This study has a number of strengths. It is a significant improvement over case-control studies that have examined similar outcomes and aero-allergen exposures. Our choice of a case-crossover design is well suited to the examination of time-varying exposures and other individual, environmental and lifestyle risk factors, such as the presence of respiratory infections. In addition, this is the first study to include complete time series data on airborne pollen exposure. This is particularly advantageous because it increases the power and reliability of the study and allows us to examine exposure threshold effects in subgroups of "at risk" children and adolescents.

\section{Limitations}

Our choice of design has inherent limitations. For a start, there is no control group for comparison, which limits our ability to address hypotheses related to non-individual specific factors. Nevertheless, of the hospital-based studies that recruited controls, almost all cited low control participation and the question of whether the controls recruited were a representative sample as major limitations.

Another limitation is how well the measurements from the one pollen monitoring station approximate the ambient concentrations across the Melbourne metropolitan region as a whole. Although there are marked daily fluctuations in airborne grass pollen levels over Melbourne during the grass pollen season (October-December), the majority of this pollen comes from grasslands to Melbourne's north, and is distributed over the city by winds blowing from this region. Thus, all subjects living in Melbourne during the study period should receive similar exposures to grass pollen [12]. However, the same may not be true for weed and tree pollen or for fungal spores, where local production means that exposure levels will probably vary across the city. Whilst measurements of pollen and fungal spores were performed at one outdoor site, it is possible that children's individual indoor 
Citation: Erbas B, Dharmage SC, O'Sullivan M, Akram M, Newbigin E, et al. (2012) A Case-Crossover Design to Examine the Role of Aeroallergens and Respiratory Viruses on Childhood Asthma Exacerbations Requiring Hospitalization: The Mapcah Study. J Biomet Biostat S7-018. doi:10.4172/2155-6180.S7-018

exposures varied. This misclassification is likely to be non-differential, which means that it would bias risk estimates towards the null.

\section{Conclusions}

We demonstrated high feasibility with daily recruitment of children with asthma admitted to a tertiary hospital by using case cross-over methodology. In addition, we demonstrated excellent validity, both internal and external. Collection of data on respiratory viruses and pollen exposure at the time of admission on children with asthma provides important information that will have an impact on both clinical practice and public health. By understanding the synergistic relationships between aeroallergens, viral infections and asthma, we can pave the way for better interventions for controlling allergies and infections in asthma, thereby helping to prevent serious asthma attacks.

\section{Acknowledgments}

MAPCAH and Shyamali Dharmage were supported by the National Health \& Medical Research Council. We acknowledge all the MAPCAH participants. We thank Associate Professor Katie Allen, Dr's Chris Birch and Julian Druce.

\section{References}

1. Eder W, Ege MJ, von Mutius E (2006) The asthma epidemic. N Engl J Med 355: 2226-2235

2. CDC, National Center for Health Statistics. FastStats - Asthma. National Center for Health Statistics.

3. Asthma UK. For journalists: key facts \& statistics

4. ACAM (2011) Asthma in Australia 2011, with a focus chapter on chronic obstructive pulmonary disease. Contract No: Cat. no. ACM 22.

5. ERS (2012) European Lung White Book

6. CDC, National Center for Health Statistics (2010) Summary Health Statistics for US Children: National Health Interview Survey.

7. Erbas B, Kelly AM, Physick B, Code C, Edwards M (2005) Air pollution and childhood asthma emergency hospital admissions: estimating intra-city regional variations. Int J Environ Health Res 15: 11-20.

8. Murray CS, Poletti G, Kebadze T, Morris J, Woodcock A, et al. (2006) Study of modifiable risk factors for asthma exacerbations: virus infection and allergen exposure increase the risk of asthma hospital admissions in children. Thorax 61: $376-382$.

9. Marks GB, Colquhoun JR, Girgis ST, Koski MH, Treloar AB, et al. (2001) Thunderstorm outflows preceding epidemics of asthma during spring and summer. Thorax 56: 468-471.

10. Newson R, Strachan D, Archibald E, Emberlin J, Hardaker P, et al. (1997) Effect of thunderstorms and airborne grass pollen on the incidence of acute asthma in England, 1990-94. Thorax 52: 680-685.

11. Erbas B, Chang JH, Dharmage S, Ong EK, Hyndman R, et al. (2007) Do levels of airborne grass pollen influence asthma hospital admissions? Clin Exp Allergy 37: 1641-1647.

12. Erbas B, Chang JH, Newbigin E, Dhamarge S (2007) Modelling atmospheric concentrations of grass pollen using meteorological variables in Melbourne Australia. Int J Environ Health Res 17: 361-368.

13. Tobias A, Galan I, Banegas JR, Aranquez E (2003) Short term effects of airborne pollen concentrations on asthma epidemic. Thorax 58: 708-710.

14. Crighton EJ, Mamdani MM, Upshur RE (2001) A population based time series analysis of asthma hospitalisations in Ontario, Canada: 1988 to 2000. BMC Health Serv Res 1: 7

15. Bizzintino J, Lee WM, Laing IA, Vang F, Pappas T, et al. (2011) Association between human rhinovirus $\mathrm{C}$ and severity of acute asthma in children. Eur Respir J 37: 1037-1042.

This article was originally published in a special issue, Medical statistics: Clinical and experimental research handled by Editor(s). Dr. Herbert Pang, Duke University, USA.
16. Galan I, Prieto A, Rubio M, Herrero T, Cervigon P, et al. (2010) Association between airborne pollen and epidemic asthma in Madrid, Spain: a case-control study. Thorax 65: 398-402

17. Grineski SE, Staniswalis JG, Bulathsinhala P, Peng Y, Gill TE (2011) Hospita admissions for asthma and acute bronchitis in El Paso, Texas: do age, sex, and insurance status modify the effects of dust and low wind events? Environ Res 111: $1148-1155$.

18. Iskandar A, Andersen ZJ, Bonnelykke K, Ellermann T, Andersen KK, et al (2012) Coarse and fine particles but not ultrafine particles in urban air trigge hospital admission for asthma in children. Thorax 67: 252-257.

19. Laurent O, Pedrono G, Segala C, Filleul L, Havard S, et al. (2008) Air pollution, asthma attacks, and socioeconomic deprivation: a small-area case-crossover study. Am J Epidemiol 168: 58-65.

20. Pereira G, Cook A, De Vos AJ, Holman CD (2010) A case-crossover analysis of traffic-related air pollution and emergency department presentations for asthma in Perth, Western Australia. Med J Aust 193: 511-514.

21. Li S, Batterman S, Wasilevich E, Elasaad H, Wahl R, et al. (2011) Asthma exacerbation and proximity of residence to major roads: a population-based matched case-control study among the pediatric Medicaid population in Detroit, Michigan. Environ Health 10: 34.

22. Karr C, Lumley T, Shepherd K, Davis R, Larson T, et al. (2006) A case-crossove study of wintertime ambient air pollution and infant bronchiolitis. Environ Health Perspect 114: 277-281.

23. Navidi W, Weinhandl E (2002) Risk set sampling for case-crossover designs Epidemiology 13: 100-105

24. Asher MI, Keil U, Anderson HR, Beasley R, Crane J, et al. (1995) Internationa Study of Asthma and Allergies in Childhood (ISAAC): rationale and methods. Eur Respir J 8: 483-91.

25. Massie J, Efron D, Cerritelli B, South M, Powell C, et al. (2004) Implementation of evidence based guidelines for paediatric asthma management in a teaching hospital. Arch Dis Child 89: 660-664.

26. National Asthma Council (Australia) (2002) Asthma Management Handbook. Melbourne2006.

27. Erbas B, Chang JH, Newbigin E, SC D (2007) Can we accurately predict ambient concentrations of allergenic grass pollen? International Journal of Environmental Health Research 17: 361-368.

28. Druce J, Tran T, Kelly H, Kaye M, Chibo D, et al. (2005) Laboratory diagnosis and surveillance of human respiratory viruses by PCR in Victoria, Australia 2002-2003. J Med Virol 75: 122-129.

29. Hill DJ, Smart IJ, Knox RB (1979) Childhood asthma and grass pollen aerobiology in Melbourne. Med J Aust 1: 426-429.

30. Pope CA 3rd, Dockery DW (1992) Acute health effects of PM10 pollution on symptomatic and asymptomatic children. Am Rev Respir Dis 145:1123-1128.

31. Ward DJ, Ayres JG (2004) Particulate air pollution and panel studies in children a systematic review. Occup Environ Med 61: e13.

32. Babin SM, Burkom HS, Holtry RS, Tabernero NR, Stokes LD, et al. (2007) Pediatric patient asthma-related emergency department visits and admissions in Washington, DC, from 2001-2004, and associations with air quality, socioeconomic status and age group. Environ Health 6: 9. 